\title{
Burkholderia phytofirmans sp. nov., a novel plant-associated bacterium with plant-beneficial properties
}

Correspondence

A. Sessitsch angela.sessitsch@arcs.ac.at
A. Sessitsch, ${ }^{1}$ T. Coenye, ${ }^{2}$ A. V. Sturz, ${ }^{3}$ P. Vandamme, ${ }^{2}$ E. Ait Barka, ${ }^{4}$ J. F. Salles, ${ }^{5}$ J. D. Van Elsas, ${ }^{6}$ D. Faure, ${ }^{7}$ B. Reiter, ${ }^{1}$ B. R. Glick, ${ }^{8}$ G. Wang-Pruski ${ }^{9}$ and J. Nowak ${ }^{10}$

${ }^{1}$ ARC Seibersdorf research $\mathrm{GmbH}$, Department of Bioresources/Microbiology, A-2444 Seibersdorf, Austria

${ }^{2}$ Laboratory of Microbiology, Universiteit Gent, Ledeganckstraat 35, B-9000 Gent, Belgium

${ }^{3}$ Prince Edward Island Department of Agriculture and Forestry, PO Box 1600, Charlottetown, PEl, Canada C1A 7N3

${ }^{4}$ Université de Reims Champagne-Ardenne, UFR Sciences, URVVC, Laboratoire de Stress, Défenses et Reproduction des Plantes, BP 1039, F-51687 Reims Cedex 2, France

${ }^{5}$ Plant Research International, Wageningen, PO Box 16, 6700 AA Wageningen,

The Netherlands

${ }^{6}$ Department of Microbial Ecology, Groningen University, Biological Center, PO Box 14, 9750 RA Haren, The Netherlands

${ }^{7}$ Institut des Sciences du Végétal, Avenue de la Terrasse, F-91198 Gif-sur-Yvette, France

${ }^{8}$ Department of Biology, University of Waterloo, Waterloo, ON, Canada N2L 3G1

${ }^{9}$ Department of Plant and Animal Sciences, Nova Scotia Agricultural College, PO Box 550, Truro, NS, Canada B2N 5E3

${ }^{10}$ Department of Horticulture, Virginia Polytechnic Institute and State University, 0327-301 Saunders Hall, Blacksburg, VA 24060, USA

A Gram-negative, non-sporulating, rod-shaped, motile bacterium, with a single polar flagellum, designated strain $\mathrm{PSJN}^{\top}$, was isolated from surface-sterilized onion roots. This isolate proved to be a highly effective plant-beneficial bacterium, and was able to establish rhizosphere and endophytic populations associated with various plants. Seven related strains were recovered from Dutch soils. Based on 16S rRNA gene sequence data, strain $\mathrm{PSJN}^{\top}$ and the Dutch strains were identified as representing a member of the genus Burkholderia, as they were closely related to Burkholderia fungorum (98.7\%) and Burkholderia phenazinium (98.5\%). Analysis of whole-cell protein profiles and DNA-DNA hybridization experiments confirmed that all eight strains belonged to a single species. Strain PSJN ${ }^{\top}$ had a DNA G $+C$ content of $61 \cdot 0 \mathrm{~mol} \%$. Only low levels of DNA-DNA hybridization to closely related species were found. Qualitative and quantitative differences in fatty acid composition between strain $\mathrm{PsJN}^{\top}$ and closely related species were identified. The predominant fatty acids in strain PsJN ${ }^{\top}$ were $16: 0,18: 1 \omega 7 c$ and summed feature 3 (comprising $16: 1 \omega 7 \mathrm{c}$ and/or iso-15:0 2-OH). Isolate $\mathrm{PsJN}^{\top}$ showed high 1-aminocyclopropane-1-carboxylate deaminase activity and is therefore able to lower the ethylene level in a developing or stressed plant. Production of the quorum-sensing signal

Abbreviations: ACC, 1-aminocyclopropane-1-carboxylate; GFP, green fluorescent protein; NAHL, N-acyl-homoserine lactone.

The GenBank/EMBL/DDBJ accession numbers for the 16S rRNA gene sequences of $B$. phytofirmans strains PsJN', G44-5 and G6-5 are AY497470, AY836218 and AY836219.

A neighbour-joining tree showing the position of $B$. phytofirmans sp. nov. within the genus Burkholderia, a dendrogram derived from the protein patterns of the strains studied and cross-sections showing chickpea roots with strain PsJNT tagged with GFP are available as supplementary figures in IJSEM Online. 
compound 3-hydroxy-C8-homoserine lactone was detected. Based on the results of this polyphasic taxonomic study, strain $\mathrm{PSJN}^{\top}$ and the seven Dutch isolates are considered to represent a single, novel species, for which the name Burkholderia phytofirmans sp. nov. is proposed. The type strain is strain $\mathrm{PSJN}^{\top}$ (= LMG $22146^{\top}=$ CCUG $49060^{\top}$ ).

Strain PsJN ${ }^{\mathrm{T}}$ (Frommel et al., 1991) was originally isolated as a contaminant from Glomus vesiculiferum-infected onion roots and was subsequently shown to be a highly effective plant-beneficial bacterium (reviewed by Nowak, 1998; Nowak \& Shulaev, 2003). Strain PsJN ${ }^{\mathrm{T}}$ is able to establish rhizosphere and endophytic populations associated with various plants, including potato, tomato and grapevines, where it stimulates plant growth (Frommel et al., 1991; Nowak et al., 1995; Pillay \& Nowak, 1997; Bensalim et al., 1998; Ait Barka et al., 2000, 2002; Compant et al., 2005) and induces developmental changes leading to better water management (Nowak et al., 1995; Lazarovits \& Nowak, 1997). Plants inoculated with strain PsJN ${ }^{\mathrm{T}}$ have been reported to produce much larger root systems, with enhanced secondary roots and more root hairs, more and larger leaf hairs, sturdier stems, and greater lignin deposits around the vascular system (Nowak, 1998). Furthermore, plants inoculated with strain PsJN ${ }^{\mathrm{T}}$ were found to contain larger amounts of phenolics and chlorophyll (Nowak et al., 1997), as well as increased levels of cytokinins (Lazarovits \& Nowak, 1997) and enhanced activity of phenylalanine ammonia lyase (Nowak et al., 1997). Strain $\mathrm{PsJN}^{\mathrm{T}}$ is also able to enhance resistance to low levels of potato pathogens (Nowak et al., 1995) and tomato pathogens (Sharma \& Nowak, 1998) as well as to reduce in vitro infection of grapevine by Botrytis cinerea (Ait Barka et al., 2000, 2002). Recently, during a field experiment performed in The Netherlands, seven strains with high 16S rRNA gene sequence similarity to strain $\mathrm{PJNN}^{\mathrm{T}}$ were isolated (RG3112, RG47-8, RG47-15, G44-5, G6-5, RG44-4, RG6-12), mainly from the bulk and rhizosphere soil of maize and grass plants growing in an old grassland field ( $>50$ years) (J. F. Salles and others, unpublished results). Additionally, in vitro dual-culture assays performed with the Dutch strains revealed that some were antagonistic to the potato pathogen Rhizoctonia solani AG-3 (Salles et al., 2005).

Based on various biochemical and physiological tests, strain $\mathrm{PsJN}^{\mathrm{T}}$ was originally classified as representing a non-fluorescent Pseudomonas sp. (Frommel et al., 1991). However, subsequent studies revealed that it represents a member of the genus Burkholderia. Phylogenetically, the genus Burkholderia belongs to the $\beta$-Proteobacteria and currently comprises more than 30 species (Coenye \& Vandamme, 2003). There are several Burkholderia species known to interact with plants. Burkholderia cepacia, the type species of the genus, was initially described as the causative agent of onion soft rot (Burkholder, 1950), but many strains belonging to the $B$. cepacia complex are also able to promote plant health (Parke \& Gurian-Sherman, 2001). Similarly, other Burkholderia species have been reported to exhibit plant-growth-promoting or biocontrol effects (El Banna \& Winkelmann, 1998; Tran Van et al., 2000; Estrada de los Santos et al., 2001).

Sequencing of the $16 \mathrm{~S}$ rRNA gene was performed as described by Reiter et al. (2002) using the primers $8 \mathrm{f}$ (5'-AGAGTTTGATCCTGGCTCAG-3'), 1520r (5'-AAGGAGGTGATCCAGCCGCA-3') and 926r (5-CCGTCAATTCCTTT(AG)AGTTT-3'). Sequence assembly was performed by using the program SEQUENCHER 4.0 (Gene Codes Corporation). Phylogenetic analysis was performed with the software package ARB (Strunk et al., 2000). Multiple alignment was performed with the MULTALIN tool (Corpet, 1988) and a neighbour-joining tree based on $1298 \mathrm{nt}$ was constructed using the TREECON software (Van de Peer \& De Wachter, 1994) (Supplementary Fig. A in IJSEM Online). The levels of similarity between strain PsJN ${ }^{\mathrm{T}}$ and the Dutch strains were $98 \cdot 8 \%$ (strain G44-5) and 99.2\% (strain G6-5). According to $16 \mathrm{~S}$ rRNA gene sequence analysis, strain $\mathrm{PsJN}^{\mathrm{T}}$ was closely related to Burkholderia fungorum LMG $16225^{\mathrm{T}}$ and Burkholderia caledonica LMG $19076^{\mathrm{T}}$ (both $98 \cdot 6 \%)$. 16S rRNA gene sequence similarity to Burkholderia phenazinium LMG $2247^{\mathrm{T}}$ and to Burkholderia terricola LMG $20594^{\mathrm{T}}$ was $98 \%$. Similarity values of $97 \cdot 8,97 \cdot 5$ and $97 \cdot 4 \%$ were found to the $16 \mathrm{~S}$ rRNA gene sequences of Burkholderia graminis $\mathrm{C} 4 \mathrm{D} 1 \mathrm{M}^{\mathrm{T}}$, Burkholderia xenovorans LMG $21463^{\mathrm{T}}$ and Burkholderia phymatum LMG $21445^{\mathrm{T}}$, respectively. Similarity levels to other Burkholderia species were below $97 \%$, and similarity levels to other genera belonging to the $\beta$-Proteobacteria were below $95 \cdot 8 \%$.

Whole-cell protein profiles of strain $\mathrm{PsJN}^{\mathrm{T}}$ and the seven Dutch strains were determined by SDS-PAGE (Coenye et al., 2001a) and compared with over 6000 profiles in a database comprising all recognized Burkholderia, Ralstonia and Pandoraea species (Coenye et al., 2001b, 2002). Computer-assisted numerical analysis and visual comparison of the whole-cell protein profiles of strain PsJN ${ }^{\mathrm{T}}$ and the seven Dutch strains revealed that they were identical to each other and were clearly different from those of the recognized Burkholderia, Ralstonia and Pandoraea reference species (Supplementary Fig. B). Determination of the cellular fatty acid profile was determined by GLC, using the Sherlock Microbial Identification System (MIDI Inc.; database TSBA40) according to a standard protocol (Paisley, 1996). Briefly, the procedure involved saponification of whole cells in methanolic $\mathrm{NaOH}$, esterification of fatty acids in acidic methanol and extraction of fatty acid methyl esters with methyl-tert-butyl ether/hexane. Strain PsJN ${ }^{\mathrm{T}}$ showed qualitative and quantitative differences in its fatty acid composition compared with closely related species. Predominant fatty acids were $16: 0,18: 1 \omega 7 c$ and summed features 2 and 3 (Table 1). A higher $18: 1 \omega 7 c$ 
Table 1. Fatty acid composition of Burkholderia phytofirmans sp. nov. PsJN ${ }^{\top}$ and related Burkholderia species

Species/strains: 1, B. phytofirmans sp. nov. $\mathrm{PsJN}^{\mathrm{T}}$; 2, B. fungorum (9 strains studied); 3, B. caledonica (7); 4, B. phenazinium (2); 5, B. graminis $(4) ; 6, B$. caribensis (2). Values are mean percentages of total fatty acids ( $\pm \mathrm{SD}$ as appropriate). Summed feature 2 comprises $14: 03$ $\mathrm{OH}$, iso-16:1 I, an unidentified fatty acid with an equivalent chain-length value of 10.928 and/or 12:0 ALDE. Summed feature 3 comprises $16: 1 \omega 7 c$ and/or iso-15:0 2-OH. Fatty acids for which the mean amount in all taxa was less than $1 \%$ are not given. tr, Trace amount $(<1 \%)$. Data for reference species are from Coenye et al. (2001a).

\begin{tabular}{|c|c|c|c|c|c|c|}
\hline Fatty acid & 1 & 2 & 3 & 4 & 5 & 6 \\
\hline $16: 0$ & $13 \cdot 8$ & $14 \cdot 7 \pm 0 \cdot 9$ & $13 \cdot 6 \pm 1 \cdot 6$ & $15 \cdot 7 \pm 2 \cdot 7$ & $14 \cdot 4 \pm 4 \cdot 7$ & $19 \cdot 1 \pm 0 \cdot 6$ \\
\hline $16: 12-\mathrm{OH}$ & $2 \cdot 3$ & $3 \cdot 5 \pm 0 \cdot 7$ & $2 \cdot 7 \pm 0 \cdot 4$ & $3 \cdot 0 \pm 1 \cdot 8$ & $5 \cdot 3 \pm 2 \cdot 2$ & $1 \cdot 7 \pm 0 \cdot 1$ \\
\hline $16: 02-\mathrm{OH}$ & $2 \cdot 1$ & $3 \cdot 6 \pm 0 \cdot 5$ & $2 \cdot 4 \pm 0 \cdot 4$ & $2 \cdot 0 \pm 1 \cdot 0$ & $3 \cdot 7 \pm 1 \cdot 6$ & $2 \cdot 2 \pm 0 \cdot 3$ \\
\hline cyclo $19: 0 \omega 8 c$ & $1 \cdot 8$ & $2 \cdot 5 \pm 0 \cdot 7$ & $3 \cdot 7 \pm 0 \cdot 7$ & $6 \cdot 3 \pm 0 \cdot 1$ & $3 \cdot 3 \pm 0 \cdot 9$ & $5 \cdot 3 \pm 0 \cdot 1$ \\
\hline $18: 12-\mathrm{OH}$ & $1 \cdot 4$ & $1 \cdot 7 \pm 0 \cdot 2$ & $1 \cdot 1 \pm 0 \cdot 3$ & $1 \cdot 6 \pm 1 \cdot 0$ & $1 \cdot 8 \pm 0 \cdot 3$ & $\operatorname{tr}$ \\
\hline Summed feature 2 & $5 \cdot 6$ & $8 \cdot 1 \pm 1 \cdot 1$ & $7 \cdot 4 \pm 0 \cdot 9$ & $7 \cdot 3 \pm 0 \cdot 7$ & $9 \cdot 8 \pm 1 \cdot 7$ & $6 \cdot 1 \pm 0 \cdot 6$ \\
\hline Summed feature 3 & $17 \cdot 6$ & $13 \cdot 6 \pm 1 \cdot 9$ & $14 \cdot 5 \pm 1 \cdot 8$ & $12 \cdot 6 \pm 0 \cdot 1$ & $15 \cdot 7 \pm 3 \cdot 0$ & $11 \cdot 2 \pm 0 \cdot 2$ \\
\hline
\end{tabular}

content was found in strain PsJN $\mathrm{N}^{\mathrm{T}}$ compared with other Burkolderia species, whereas strain $\mathrm{PsJN}^{\mathrm{T}}$ produced lower levels of $14: 0$, cyclo $17: 0$ and cyclo $19: 0 \omega 8 c$ fatty acids. In addition to these differences, strain $\mathrm{PsJN}^{\mathrm{T}}$ showed different levels of 16:0 3-OH, and summed features 2 and 3 compared with B. fungorum and B. caledonica (Table 1).

Strain PsJN ${ }^{\mathrm{T}}$ was originally recovered on King's B medium (King et al., 1954) incubated at $30^{\circ} \mathrm{C}$ (method outlined in Nowak \& Shulaev, 2003), and forms beige-coloured colonies on 1:10 strength trypticase soy agar (Becton-Dickinson) at $30^{\circ} \mathrm{C}$ but not at $37^{\circ} \mathrm{C}$. Classical phenotypic tests were performed with strain $\mathrm{PsJN}^{\mathrm{T}}$ and all Dutch strains as described by Vandamme et al. (1993) and Coenye et al. (2001a). API ZYM, API20 NE, ONPG and PNPG tests were performed according to the recommendations of the manufacturer (bioMérieux). Results of the phenotypic analyses are shown in Table 2 and in the species description. Strain PsJN ${ }^{\mathrm{T}}$ and the seven Dutch strains could be distinguished from closely related Burkholderia species such as B. fungorum and B. caledonica on the basis of additional biochemical properties, including growth in $10 \%$ lactose, no growth at $37^{\circ} \mathrm{C}$, no nitrate reduction and oxidase activity (Table 2 ).

DNA-DNA hybridization experiments were performed as described by Coenye et al. (2001a). Based on 16S rRNA gene sequence data, protein profiles and biochemical data, B. fungorum, B. terricola, Burkholderia caribensis and B. xenovorans were selected as reference strains for DNADNA hybridization experiments. Strain $\mathrm{PsJN}^{\mathrm{T}}$ and strain R23375 (one of the Dutch isolates) showed a high DNADNA hybridization value $(90 \%)$. In contrast, strain $\mathrm{PsJN}^{\mathrm{T}}$ showed relatively low DNA-DNA hybridization values towards B. fungorum LMG $16225^{\mathrm{T}}(27 \%)$, B. terricola LMG $20594^{\mathrm{T}}(21 \%)$, B. caribensis LMG $18531^{\mathrm{T}}(17 \%)$,
B. graminis LMG $18924^{\mathrm{T}}$ (11\%), B. caledonica LMG $19076^{\mathrm{T}}$ $(36 \%)$ and B. xenovorans LMG $21463^{\mathrm{T}}(9 \%)$.

The $\mathrm{G}+\mathrm{C}$ content of the DNA was determined as described by Coenye et al. (2001a). Strains PsJN ${ }^{\mathrm{T}}$ and R23375 had $\mathrm{G}+\mathrm{C}$ contents of $61 \cdot 0$ and $62 \cdot 1 \mathrm{~mol} \%$, respectively, matching well with values for closely related species.

In order to show the endophytic colonization potential of strain $\mathrm{PsJN}^{\mathrm{T}}$, a green fluorescent protein (GFP)-tagged derivative was applied for visualization of the strain on chickpea (Cicer arietinum L.) plants. Plants were inoculated with cells of the GFP-tagged $\mathrm{PsJN}^{\mathrm{T}}$ strain $\left[10^{7}\right.$ c.f.u. ( $\mathrm{g}$ vermiculite $\left.)^{-1}\right]$ as described by Ait Barka et al. (2000). Plants were harvested at different times after sowing. Aggregations of GFP-expressing bacterial cells were visualized by using an Olympus fluorescence stereomicroscope (model $\mathrm{BH} 2$ ) equipped with a double set of fluorescence filters. The filter sets consisted of a 450-490 nm band-pass excitation filter and a $520 \mathrm{~nm}$ suppressor filter. Microscopic analyses were performed on live intact plant tissue. Just 1 day after incubation, the rhizoplane was densely colonized by strain PsJN ${ }^{\mathrm{T}}$. More GFP-expressing cells were found on lateral roots than on the main root, and root cracks resulting from lateral root emergence were densely colonized. Four days after inoculation, $\mathrm{PsJN}^{\mathrm{T}}$ cells were found in association with root epidermal cells, parenchyma cells (Supplementary Fig. C) and xylem vessels (Supplementary Fig. D). After 6 days, $\mathrm{PsJN}^{\mathrm{T}}$ also colonized stems and leaves endophytically. In addition to chickpea endophytic colonization, the potential of strain $\mathrm{PsJN}^{\mathrm{T}}$ was also shown with potato (Frommel et al., 1991), tomato (Pillay \& Nowak, 1997) and grapevines (Ait Barka et al., 2002).

Activity of the enzyme 1-aminocyclopropane-1-carboxylate (ACC) deaminase was determined according to Penrose \& 
Table 2. Phenotypic characteristics of $B$. phytofirmans sp. nov. in comparison with related Burkholderia species

Species: 1, B. phytofirmans sp. nov. (8 strains tested); 2, B. fungorum (9); 3, B. caledonica (7); 4, B. phenazinium (2);5, B. graminis (4); 6, B. caribensis (2). Characteristics of type strains are scored as positive $(+)$ or negative $(-) ; \mathrm{V}(+)$, strain dependent, type strain positive; $\mathrm{v}(-)$, strain dependent, type strain negative. Data for reference species are taken from Coenye et al. (2001a). The following features are positive for all type strains: growth at $30{ }^{\circ} \mathrm{C}$, hydrolysis of Tween 80 , assimilation of L-arabinose, $\mathrm{N}$ acetylglucosamine, D-glucose, D-mannose, D-mannitol, D-gluconate, phenylacetate and L-malate and activity for acid and alkaline phosphatase, $\mathrm{C}_{8}$-esterase lipase and leucine arylamidase. The following features are negative for all type strains: haemolysis, growth at $42{ }^{\circ} \mathrm{C}$, production of fluorescent pigment, growth in the presence of $4.5 \% \mathrm{NaCl}$, production of acid or $\mathrm{H}_{2} \mathrm{~S}$ in triplesugar-iron agar, assimilation of maltose, aesculin hydrolysis and activity for DNase, urease, gelatinase, tryptophan deaminase, $\alpha$-glucosidase, $\alpha$-galactosidase, $\alpha$-fucosidase, $\alpha$-mannosidase, $\beta$ glucuronidase, trypsin, $\alpha$-chymotrypsin, arginine dehydrolase, ornithine decarboxylase and $\mathrm{N}$-acetylglucosaminidase.

\begin{tabular}{|c|c|c|c|c|c|c|}
\hline Characteristic & 1 & 2 & 3 & 4 & 5 & 6 \\
\hline Oxidase activity & + & $\mathrm{v}(+)$ & - & $\mathrm{v}(+)$ & $\mathrm{V}(-)$ & - \\
\hline Growth at $37^{\circ} \mathrm{C}$ & - & + & $\mathrm{V}(-)$ & $\mathrm{v}(+)$ & + & + \\
\hline \multicolumn{7}{|c|}{ Growth in OF medium with: } \\
\hline D-Glucose & + & + & + & $\mathrm{V}(-)$ & $\mathrm{v}(+)$ & + \\
\hline Maltose & $\mathrm{v}(-)$ & $\mathrm{V}(-)$ & $\mathrm{v}(+)$ & $\mathrm{V}(-)$ & - & - \\
\hline Adonitol & - & $\mathrm{V}(-)$ & $\mathrm{v}(+)$ & - & $\mathrm{v}(+)$ & $\mathrm{v}(+)$ \\
\hline D-Fructose & + & $\mathrm{V}(+)$ & + & + & + & $\mathrm{v}(+)$ \\
\hline D-Xylose & + & $\mathrm{v}(+)$ & + & $\mathrm{V}(-)$ & $\mathrm{v}(+)$ & - \\
\hline Growth on cetrimide & $\mathrm{v}(+)$ & $\mathrm{v}(+)$ & - & - & - & - \\
\hline Nitrate reduction & - & + & - & - & + & - \\
\hline \multicolumn{7}{|c|}{ Growth in the presence of: } \\
\hline $0 \cdot 5 \% \mathrm{NaCl}$ & + & + & $\mathrm{v}(+)$ & - & $\mathrm{V}(+)$ & - \\
\hline $1 \cdot 5 \% \mathrm{NaCl}$ & $\mathrm{v}(+)$ & $\mathrm{v}(+)$ & $\mathrm{V}(-)$ & - & $\mathrm{v}(+)$ & - \\
\hline $3 \cdot 0 \% \mathrm{NaCl}$ & $\mathrm{V}(+)$ & - & - & - & - & - \\
\hline $4 \cdot 5 \% \mathrm{NaCl}$ & $\mathrm{V}(-)$ & - & - & - & - & - \\
\hline $10 \%$ Lactose & + & - & $\mathrm{v}(+)$ & - & - & - \\
\hline \multicolumn{7}{|l|}{ Activity of: } \\
\hline $\mathrm{C}_{4}$-esterase & + & $\mathrm{v}(+)$ & $\mathrm{V}(-)$ & + & $\mathrm{v}(+)$ & $\mathrm{v}(-)$ \\
\hline $\mathrm{C}_{14}$-lipase & - & $\mathrm{v}(-)$ & - & - & - & - \\
\hline$\beta$-Galactosidase & - & - & - & - & - & + \\
\hline Acetamide deamidase & $\mathrm{V}(-)$ & - & - & - & - & - \\
\hline
\end{tabular}

Glick (2003). ACC deaminase, commonly found in plantgrowth-promoting rhizobacteria (e.g. Shah et al., 1998), cleaves the plant ethylene ACC, thereby lowering the ethylene level in a developing or stressed plant. Strain PsJN ${ }^{\mathrm{T}}$ had high ACC deaminase activity; it was able to cleave $308 \mathrm{nmol} \alpha$-ketobutyrate $(\mathrm{mg} \text { protein })^{-1} \mathrm{~min}^{-1}$. It has been reported that $\geqslant 20 \mathrm{nmol} \alpha$-ketobutyrate $(\mathrm{mg} \text { protein })^{-1}$ $\mathrm{min}^{-1}$ is sufficient to show plant-growth-promoting effects (Penrose \& Glick, 2003).

Many bacteria have evolved mechanisms to allow gene expression only when cell density is appropriate. This phenomenon is known as quorum sensing (for reviews see, for example, Whitehead et al., 2001; Fuqua \& Greenberg, 2002), which, in Gram-negative bacteria, is mediated by $N$ acyl-homoserine lactones (NAHLs). These low-molecularmass compounds diffuse in and out of bacterial cells and control important biological functions such as pathogenicity or plant-growth-promoting functions (Pierson et al., 1998). The production of NAHLs is common among $B$. cepacia strains (Gotschlich et al., 2001) and was found to control the synthesis of protease and siderophores (Lutter et al., 2001; Lewenza et al., 1999). NAHL production by strain PsJN ${ }^{\mathrm{T}}$ was determined here by TLC as described by Shaw et al. (1997). PsJN ${ }^{\mathrm{T}}$ extracts and pure NAHL were visualized with the biosensors Chromobacterium violaceum CV026 (McClean et al., 1997) and Agrobacterium tumefaciens NTLR4 (Cha et al., 1998). Results indicated the production of 3-hydroxy-C8-homoserine lactone in strain PsJN ${ }^{\mathrm{T}}$.

\section{Description of Burkholderia phytofirmans sp. nov.}

Burkholderia phytofirmans (phy.to.fir'mans. Gr. n. phyton plant; L. part. adj. firmans strengthening; N.L. part. adj. phytofirmans plant-strengthening).

Cells are Gram-negative, non-sporulating, straight rods, $0 \cdot 5-0 \cdot 8 \mu \mathrm{m}$ wide and $0 \cdot 8-1 \cdot 8 \mu \mathrm{m}$ long, and are motile by a single polar flagellum (Frommel et al., 1991). Growth is observed at $30^{\circ} \mathrm{C}$ but not at $37^{\circ} \mathrm{C}$. Nitrate and nitrite are not reduced. Able to assimilate D-fructose, D-xylose and Dglucose but not adonitol. Growth occurs in the presence of $0.5 \% \mathrm{NaCl}$ and $10 \%$ lactose. Additional characteristics are listed in Table 2 . The following fatty acids are present in significant amounts (above 1\%): 14:0, 16:0, cyclo $17: 0$, $16: 12-\mathrm{OH}, 16: 02-\mathrm{OH}, 16: 03-\mathrm{OH}, 18: 1 \omega 7 c$, $18: 0$, cyclo $19: 0 \omega 8 c, 18: 12-\mathrm{OH}$, summed feature 2 (comprising 14:0 $3-\mathrm{OH}$, iso-16:1 $\mathrm{I}$, an unidentified fatty acid with an equivalent chain-length value of 10.928 and/or 12:0 ALDE) and summed feature 3 (comprising $16: 1 \omega 7 c$ and/or iso$15: 02-\mathrm{OH})$. The $\mathrm{G}+\mathrm{C}$ content is $61 \cdot 0-62 \cdot 1 \mathrm{~mol} \%$.

The type strain, PsJN ${ }^{\mathrm{T}}\left(=\mathrm{LMG} 22146^{\mathrm{T}}=\right.$ CCUG $\left.49060^{\mathrm{T}}\right)$, was isolated from surface-sterilized onion roots at the Nova Scotia Agricultural College, Truro, NS, Canada (Nowak et al., 1997). Other strains (LMG 22849-LMG 22855) were isolated from the rhizosphere of maize and grasses and from the bulk soil of a Dutch field. The properties of the type strain are the same as described above for the species. In addition, the type strain will grow on cetrimide and in the presence of 1.5 and $3.0 \% \mathrm{NaCl}$, will not grow in $\mathrm{OF}$ medium with maltose or in the presence of $4.5 \% \mathrm{NaCl}$ and does not show acetamide deamidase activity. The $\mathrm{G}+\mathrm{C}$ content of the type strain is $61 \cdot 0 \mathrm{~mol} \%$.

\section{Acknowledgements}

T.C. and P.V. are indebted to the Fund for Scientific Research Flanders (Belgium) for a position as postdoctoral fellow and research 
grants, respectively. T. C. also acknowledges support from the Belgian Federal Government (Federal Office for Scientific, Technical and Cultural Affairs). We are grateful to Professor Dr Hans Trüper for help with the nomenclature.

\section{References}

Ait Barka, E., Belarbi, A., Hachet, C., Nowak, J. \& Audran, J.-C. (2000). Enhancement of in vitro growth and resistance to gray mould of Vitis vinifera co-cultured with plant growth-promoting rhizobacteria. FEMS Microbiol Lett 186, 91-95.

Ait Barka, E., Gognies, S., Nowak, J., Audran, J.-C. \& Belarbi, A. (2002). Inhibitory effect of endophyte bacteria on Botrytis cinerea and its influence to promote the grapevine growth. Biol Control 24, 135-142.

Bensalim, S., Nowak, J. \& Asiedu, S. K. (1998). A plant growth promoting rhizobacterium and temperature effects on performance of 18 clones of potato. Am J Potato Res 75, 145-152.

Burkholder, W. H. (1950). Sour skin, a bacterial rot of onion bulbs. Phytopathology 40, 115-117.

Cha, C., Gao, P., Chen, Y. C., Shaw, P. D. \& Farrand, S. K. (1998). Production of acyl-homoserine lactone quorum-sensing signals by gram-negative plant-associated bacteria. Mol Plant Microbe Interact 11, 1119-1129.

Coenye, T. \& Vandamme, P. (2003). Diversity and significance of Burkholderia species occupying diverse ecological niches. Environ Microbiol 5, 719-729.

Coenye, T., Laevens, S., Willems, A., Ohlén, M., Hannant, W., Govan, J. R. W., Gillis, M., Falsen, E. \& Vandamme, P. (2001a). Burkholderia fungorum sp. nov. and Burkholderia caledonica sp. nov., two new species isolated from the environment, animals and human clinical samples. Int J Syst Evol Microbiol 51, 1099-1107.

Coenye, T., Vandamme, P., Govan, J. R. W. \& LiPuma, J. J. (2001b). Taxonomy and identification of the Burkholderia cepacia complex. J Clin Microbiol 39, 3427-3436.

Coenye, T., Goris, J., Spilker, T., Vandamme, P. \& LiPuma, J. J. (2002). Characterization of unusual bacteria isolated from respiratory secretions of cystic fibrosis patients and description of Inquilinus limosus gen. nov., sp. nov. J Clin Microbiol 40, 2062-2069.

Compant, S., Reiter, B., Sessitsch, A., Nowak, J., Clement, C. \& Ait Barka, E. (2005). Endophytic colonization of Vitis vinifera L. by plant growth-promoting bacterium Burkholderia sp. strain PsJN. Appl Environ Microbiol 71, 1685-1693.

Corpet, F. (1988). Multiple sequence alignment with hierarchical clustering. Nucleic Acids Res 16, 10881-10890.

El Banna, N. \& Winkelmann, G. (1998). Pyrrolnitrin from Burkholderia cepacia: antibiotic activity against fungi and novel activities against streptomycetes. J Appl Microbiol 85, 69-78.

Estrada de los Santos, P., Bustillos-Cristales, R. \& CaballeroMellado, J. (2001). Burkholderia, a genus rich in plant-associated nitrogen fixers with wide environmental and geographic distribution. Appl Environ Microbiol 67, 2790-2798.

Frommel, M. I., Nowak, J. \& Lazarovits, G. (1991). Growth enhancement and developmental modifications of in vitro grown potato (Solanum tuberosum ssp. tuberosum) as affected by a nonfluorescent Pseudomonas sp. Plant Physiol 96, 928-936.

Fuqua, C. \& Greenberg, E. P. (2002). Listening in on bacteria: acylhomoserine lactone signalling. Nat Rev Mol Cell Biol 3, 685-695.

Gotschlich, A., Huber, B., Geisenberger, O. \& 11 other authors (2001). Synthesis of multiple $N$-acylhomoserine lactones is widespread among the members of the Burkholderia cepacia complex. Syst Appl Microbiol 24, 1-14.
King, E. O., Ward, M. K. \& Raney, D. E. (1954). Two simple media for the demonstration of pycocyanin and fluorescein. J Lab Clin Med 44, 301-307.

Lazarovits, G. \& Nowak, J. (1997). Rhizobacteria for improvement of plant growth and establishment. HortScience 32, 188-192.

Lewenza, S., Conway, B., Greenberg, E. P. \& Sokol, P. A. (1999). Quorum sensing in Burkholderia cepacia: identification of the LuxRI homologs CepRI. J Bacteriol 181, 748-756.

Lutter, E., Lewenza, S., Dennis, J. J., Visser, M. B. \& Sokol, P. A. (2001). Distribution of quorum-sensing genes in the Burkholderia cepacia complex. Infect Immun 69, 4661-4666.

McClean, K. H., Winson, M. K., Fish, L. \& 9 other authors (1997). Quorum sensing and Chromobacterium violaceum: exploitation of violacein production and inhibition for the detection of $\mathrm{N}$ acylhomoserine lactones. Microbiology 143, 3703-3711.

Nowak, J. (1998). Benefits of in vitro "biotization" of plant tissue cultures with microbial inoculants. In Vitro Cell Dev Biol Plant 34, 122-130.

Nowak, J. \& Shulaev, V. (2003). Priming for transplant stress resistance in in vitro propagation. In Vitro Cell Dev Biol Plant 39, 107-124.

Nowak, J., Asiedu, S. K. \& Lazarovits, G. (1995). Enhancement of in vitro growth and transplant stress tolerance of potato and vegetable plants co-cultured with a plant growth promoting rhizobacterium. In Ecophysiology and Photosynthetic In Vitro Cultures, pp. 173-180. Edited by F. Carre \& P. Chagvardieff. Aix-en-Provence: CEA.

Nowak, J., Asiedu, S. K., Bensalim, S., Richards, J., Stewart, A., Smith, C., Stevens, D. \& Sturz, A. V. (1997). From laboratory to applications: challenges and progress with in vitro dal cultures of potato and beneficial bacteria. In Pathogen and Microbial Contamination Management in Micropropagation, pp. 321-329. Edited by A. Cassells. Dordrecht: Kluwer Academic Publishers.

Paisley, R. (1996). MIS Whole Cell Fatty Acid Analysis by Gas Chromatography Training Manual. Newark, DE: MIDI, Inc.

Parke, J. L. \& Gurian-Sherman, D. (2001). Diversity of the Burkholderia cepacia complex and implications for risk assessment of biological control strains. Annu Rev Phytopathol 39, 225-258.

Penrose, D. M. \& Glick, B. R. (2003). Methods for isolating and characterizing ACC deaminase-containing plant growth-promoting rhizobacteria. Physiol Plant 118, 10-15.

Pierson, L. S., III, Wood, D. W. \& Pierson, E. A. (1998). Homoserine lactone-mediated gene regulation in plant-associated bacteria. Аnnu Rev Phytopathol 36, 207-225.

Pillay, V. K. \& Nowak, J. (1997). Inoculum density, temperature, and genotype effects on in vitro growth promotion and epiphytic and endophytic colonization of tomato (Lycopersicon esculentum L.) seedlings inoculated with a pseudomonad bacterium. Can J Microbiol 43, 354-361.

Reiter, B., Pfeifer, U., Schwab, H. \& Sessitsch, A. (2002). Response of endophytic bacterial communities in potato plants to infection with Erwinia carotovora subsp. atroseptica. Appl Environ Microbiol 68, 2261-2268.

Salles, J. F., van Elsas, J. D. \& van Veen, J. A. (2005). Effect of agricultural management regimes on Burkholderia community structure in soil. Microb Ecol (in press).

Shah, S., Li, J., Moffatt, B. A. \& Glick, B. R. (1998). Isolation and characterization of ACC deaminase genes from two different plant growth-promoting rhizobacteria. Can J Microbiol 44, 833-843.

Sharma, V. \& Nowak, J. (1998). Enhancement of verticillium wilt resistance in tomato transplants by in vitro co-culture of seedlings with a plant growth promoting rhizobacterium (Pseudomonas sp. strain PsJN). Can J Microbiol 44, 528-536. 
Shaw, P. D., Ping, G., Daly, S. L., Cha, C., Cronan, J. E., Jr, Rinehart, K. L. \& Farrand, S. K. (1997). Detecting and characterizing $N$-acylhomoserine lactone signal molecules by thin-layer chromatography. Proc Natl Acad Sci U S A 94, 6036-6041.

Strunk, O., Gross, O., Reichel, B. \& 11 other authors (2000). ARB: a software environment for sequence data. http://www.arb-home.de/

Tran Van, V., Berge, O., Ngo, K. S., Balandreau, J. \& Heulin, T. (2000). Repeated beneficial effects of rice inoculation with a strain of Burkholderia vietnamiensis on early and late yield components in low fertility sulphate acid soils of Vietnam. Plant Soil 218, 273-284.
Vandamme, P., Gillis, M., Vancanneyt, M., Hoste, B., Kersters, K. \& Falsen, E. (1993). Moraxella lincolnii sp. nov., isolated from the human respiratory tract, and reevaluation of the taxonomic position of Moraxella osloensis. Int J Syst Bacteriol 43, 474-481.

Van de Peer, Y. \& De Wachter, R. (1994). TREECON for Windows: a software package for the construction and drawing of evolutionary trees for the Microsoft Windows environment. Comput Appl Biosci 10, 569-570.

Whitehead, N. A., Barnard, A. M. L., Slater, H., Simpson, N. J. L. \& Salmond, G. P. C. (2001). Quorum sensing in Gram-negative bacteria. FEMS Microbiol Rev 25, 365-404. 